\title{
Chinese and English Enterprise Publicity: A Rhetorical Comparison and Translation
} \\ ${ }^{1}$ College of Humanities and Law, Fujian Agriculture and Forestry University, Fuzhou, China \\ ${ }^{2}$ College of Economics, Fujian Agriculture and Forestry University, Fuzhou, China \\ *cjgullit@163.com
}

\begin{abstract}
Enterprise publicity, to a great extent, contributes to a favorable enterprise image and promotes the reputation of its services and goods. This paper, by collecting ten profiles of Chinese central state-owned enterprises and ten American enterprise profiles, makes a contrastive rhetorical analysis in terms of their arguments, textual arrangements and appeals. It puts forth that Chinese enterprise profiles are inclined to highlight the company's information in long and high-profile appeals, while American enterprise profiles are more succinct and fact-oriented. It also argues that realization of informative function and operative function should be regarded as the criteria for translation of enterprise publicity, with priority given to the latter. Several translation strategies including adaptation, restructuring and simplification plus rewriting are explored with the aim of realizing the intended functions of the target text.
\end{abstract}

Keywords: Enterprise publicity, Rhetorical comparison, Text functions, Translation strategies.

\section{Introduction}

Against the backdrop of economic globalization, many a Chinese enterprise expands their business into the global market. To publicize their enterprises so as to offer a quick and unchallenging access to overseas clients, many Chinese enterprises have established English websites.

Enterprise profile, an indispensable part of the promotional materials, displays the strength and credibility of the company and serves as a platform to build up a positive reputation of an enterprise through promoting its services and goods. However, some translation errors are identified in the Chinese central state-owned enterprises' (hereinafter referred to as "central SOEs”) publicity. This paper, making a comparison of the rhetorical features between Chinese central SOEs and American enterprise profiles, aims to study the strategies for Chinese-English translation of enterprise publicity.

\section{A Rhetorical Comparison of Chinese and American Enterprise Publicity}

Enterprise profile usually incorporates the information such as history, leadership, location, scope of goods or services, financials, enterprise values, management and vision. A contrastive rhetorical analysis will shed new light on the translation strategies of enterprise profiles due to the reason that "both translation and rhetoric are real-life discursive practices focusing on centrality of audience and how symbolic power is generated through effective use of symbolic resources" ${ }^{\text {[1] }}$. The data of this paper consist of ten Chinese central SOEs and ten American enterprise profiles, all of which are listed as Fortune 500.

\subsection{Differences in Arguments}

From the data it can be observed that English translations of the ten Chinese corporate profiles have an average of 481 words (table 1), which is nearly twice as long as American corporate profiles (table 2). This is possibly because Chinese corporate profiles are inclined to highlight the company's strength, social status, history, vision and awards in long descriptions with detailed information or even high-profile discourse. Compared with Chinese corporate profiles, English ones are succinct, clear and to the point, and focus more on the advantages of their products, services and technology with concrete facts and figures to attract customers. 
Table 1. Statistics of English translations of ten Chinese central SOEs

\begin{tabular}{|c|c|c|c|}
\hline Chinese Central SOEs & English Abbreviations & Paragraphs & Words \\
\hline 神华集团 & Shenhua & 5 & 364 \\
\hline 中国华能 & CHNG & 5 & 504 \\
\hline 中国五矿 & CMC & 6 & 553 \\
\hline 中粮 & COFCO & 8 & 424 \\
\hline 中国建筑 & CSCEC & 11 & 938 \\
\hline 中国一汽 & FAW & 5 & 330 \\
\hline 中国中冶 & MCC & 7 & 733 \\
\hline 中国石化 & Sinochem & 4 & 335 \\
\hline 国家电网 & SGCC & 2 & 155 \\
\hline \multicolumn{2}{|c|}{ Average } & 5.9 & 481.8 \\
\hline
\end{tabular}

Table 2. Statistics of ten American enterprise profiles

\begin{tabular}{|c|c|c|c|}
\hline American Companies & Abbreviations & Paragraphs & Words \\
\hline JPMorgan Chase \& Co. & JPM & 7 & 105 \\
\hline Wal-Mart & Wal-Mart & 1 & 103 \\
\hline CHS & CHS & 6 & 256 \\
\hline American Telephone \& Telegraph & AT\&T & 11 & 387 \\
\hline Boeing & Boeing & 9 & 683 \\
\hline Citibank & Citi & 2 & 121 \\
\hline Procter \& Gamble & P\&G & 1 & 48 \\
\hline Hewlett-Packard Development Company & HP & 3 & 90 \\
\hline MCKESSON & MCKESSON & 7 & 149 \\
\hline Average & & 5.2 & 258.9 \\
\hline
\end{tabular}

\subsection{Differences in Textual Arrangements}

The textual arrangements of Chinese and American enterprise profiles generally follow an identical pattern, that is, both are developed in linear progression with complete information ${ }^{[2]}$. Nevertheless, some differences still exist in textual norms (table 3).

Table 3. A contrast of textual arrangements between Chinese and American enterprise profiles

\begin{tabular}{|c|c|}
\hline $\begin{array}{l}\text { General textual arrangements of } \\
\text { ten Chinese Central SOEs }\end{array}$ & $\begin{array}{l}\text { General textual arrangements of } \\
\text { ten American Enterprise }\end{array}$ \\
\hline $\begin{array}{l}\text { (1) history - nature - financial status - } \\
\text { business scope - achievements - vision } \\
\text { (2) nature - history - achievements - } \\
\text { financial status - business scope - } \\
\text { vision }\end{array}$ & $\begin{array}{l}\text { Nature - business scope and } \\
\text { performance - (history) - career - } \\
\text { commitment, vision and mission }\end{array}$ \\
\hline
\end{tabular}

It can be observed that the information in Chinese corporate profiles are arrayed in a random and illogical way. As for American enterprise profiles, the textual arrangement is relatively organized: the beginning is to highlight the enterprise nature, followed by business scope, enterprise performance and financial status, etc., and the vision of enterprise is located at the end.

\subsection{Differences in Appeals}

As proposed by Herrick, "Appeals are those symbolic strategies that aim either to elicit an emotion or to engage the audience's loyalties or commitments" ${ }^{[3]}$. Different cultural systems and social backgrounds yield divergent modes of appeal.

With the influence of politics on economy, terms with specific cultural characteristics are often found in Chinese enterprise profiles. Various awards and ideological discourse are always placed in prominent forms, for they are regarded as one of the best appeals to customers' recognition and to 
establish a company's credibility in Chinese culture. By contrast, American enterprises appeal to readers by highlighting the facts including high reputation (We aim to be the most respected financial services firm in the world, serving corporations and individuals in over 100 countries), excellent customer service (We work hard every day to make quality products and services that improve people's lives, now and for generations to come), corporate responsibilities (It's all part of our unwavering commitment to creating opportunities and bringing value to customers and communities around the world), etc. in a plain and objective tone.

\section{Text Functions and Translation Criteria of Enterprise Publicity}

Before we explore the concrete strategies for translating enterprise publicity, it will be of great help to understand text typology because "lack of relevant knowledge of genre, communicative functions, text types and culture may result in distorted translations" [4]. Reiss classifies the texts into three categories, namely, informative text, expressive text and operative text ${ }^{[5]}$. Baker advances that "no actual text will exhibit only one language function, and many texts cannot be assigned to one specific text type only" ${ }^{[6]}$. In other words, enterprise profile should also be regarded as multifunctional text.

The major functions of enterprise profile are to attract the reader's attention and to urge them to recognize the value and services of the enterprise. At the same instant, a good translation of the enterprise profile not only contributes to a favorable enterprise image, but more importantly helps to expand overseas market and ultimately drives customers' purchasing and attracts foreign investment. In this regard, the leading function of enterprise profile is operative, which runs through the text in an underlying manner. Enterprise profile is also informative in that it provides necessary and adequate information like the scope of goods or services, location, facility and so on for readers.

However, the informative function of corporate profile is subordinate to its operative function. The publicity will be ineffective and futile if it fails to realize the operative function, or to be specific, fail to arouse readers' interest or impulse to take certain actions like purchase. Therefore, translators must ensure that both informative function and operative function are realized, and if there are conflicts between the two functions, priority should be given to the latter.

\section{Chinese-English Translation Strategies of Enterprise Publicity}

Based on the exploration of rhetorical comparison, text functions and translation criteria of enterprise publicity, this following part of the paper will probe into the Chinese-English translation strategies for enterprise profiles from the perspective of instrumental translation proposed by Nord which can be interpreted as "the translation result is a text that may achieve the same range of functions as an original text” ${ }^{[7]}$.

\subsection{Adaptation}

The fundamental purpose of corporate profiles is to offer information, stimulate consumption and establish business relationship. Due to the differences in arguments between Chinese and American enterprise profiles, translator should not only make linguistic adaptations but also adapt to the cultural conventions, thinking norms as well as aesthetic values of target community.

Hyperbole descriptive information, whose transferability is low in translation, are often detected in Chinese corporate profiles. Translators should adapt to the target textual conventions by filtering the redundant descriptions and reproduce the concrete information.

Example 1: 伴随着新中国前进发展的脚步, 几代一汽人走过了史诗般的创业拼搏历程，在 新中国汽车工业发展史上写下了可歌可泣的壮丽篇章。第一次创业，一汽人发扬艰苦创业、 刻苦学习的精神，在荒原上创造了三年建厂并投产的奇迹，结束了中国不能制造汽车的历 史; …… (中国第一汽车集团公司)

China FAW Group Corporation, commonly referred to as FAW due to its original name of First Automotive Works, broke ground for its first factory on July 15, 1953. FAW produced China's first Jiefang commercial truck in 1956, and in the year 1958, China's first Dongfeng car and first Hongqi 
luxury sedan rolled off the production. Since then, FAW has been at the forefront of promoting China's automotive industry.

Example 2: 2015年，神华集团上下团结一心，积极主动适应经济新常态，紧紧围绕 “1245” 清洁能源发展战略, 生产经营取得了难能可贵的成绩。（神华集团）

Suggested translation: In 2015, Shenhua Group has grown significantly and benefited from the new normal of China's economy and the strategic focus on developing clean energy.

In the above examples, to ensure that content and language are easily acceptable and understandable to the readers, the English translations adopt plainer versions that make the information easier to understand. In Example 1, the translator adapts the high-sounding comments to plain narration of FAW's historical events due to the reason that "the western audience simply will not read long glowing descriptions of your product, and are not impressed by elaborate descriptions, extravagant claims, or of the awards that have been won from agencies that are unknown outside China" ${ }^{[8]}$. In Example 2, the subjective comments in the source text are not translated literally into the target text. Instead, the suggested translation adapts to the target audience's expectation by transforming the subjective comments into concrete facts.

\subsection{Restructuring}

Restructuring is a skill aiming to make "a stylistic form appropriate to the receptor language and to the intended receptors” ${ }^{[9]}$. As investigated in section 2.2, Chinese and English enterprise profiles follow contrasting textual norms. A literal copying of the Chinese textual arrangement in translation will probably not engage the readers' interests. The English version is suggested to accommodate to the target textual conventions.

It is observed in the ten American enterprise profiles that the first person "we" is preferred to narrow the distance with prospective clients. On the other hand, American enterprise profiles are usually written in subsections with first person headings, which sets a good example for the C-E translation of Chinese enterprise profiles. Therefore, the translator can reorganize the source text under headings like "Who We Are" (giving a general description about the company), "What We Do" (introducing the products or services the company offers), "Our People” (introducing the qualification and career development of staff), "Our Goal and Commitment” (indicating the vision of the company), etc. to better cater to the expectation of target readers.

\subsection{Simplification Plus Rewriting}

From the perspective of Skopos Theory, the source text is merely an offer of information, from which translator selects the information that can help to achieve the intended function according to the translation brief. Information that may obstruct the fulfilling of the predominant function in the target text can be simplified or rewritten.

As explored in previous discussion, Chinese enterprises are prone to present their honors and awards or adopt subjective comments in their profiles. However, it does not suit the target cultural norms if the honors, awards and subjective comments are faithfully reproduced in a lengthy text. It is more advisable to rewrite this kind of information to arouse the interests of target readers and to produce a target text which is both readership-oriented and effect-oriented.

Example 3: “十二五” 期间，中国建筑获得国家科技奖12项（一等奖3项，技术发明奖2 项）， 詹天佑奖38项，各类省部级科技奖880项，国家级工法146项，主参编国家标准46项，国家授 权专利8617项，获国务院国资委颁发的中央企业“科技创新企业奖”。（中国建筑股份有限 公司)

Suggested translation: CSCEC continues to be acknowledged for industry leadership, project excellence and technology innovation. For our clients, this recognition confirms CSCEC's ability to successfully, ethically and safely execute projects around the world. (Click "Recognitions and Awards" to view a few notable awards).

In the suggested translation of Example 3, the information of awards and honorary titles, though commonly seen in Chinese texts, is rewritten for the sake of achieving the operative function in the 
target culture. On the other hand, a hyperlink is provided to demonstrate the notable awards to accommodate to the target community.

Example 4: 铜、锌、镍等资源量进入世界第一梯队, 铇、锑、铋资源量位居全球第一; 公 司积累了贯穿各环节的核心技术优势和设计施工能力，承担了中国大中型钢铁企业超过 $90 \%$ 的设计施工任务和全球 $60 \%$ 冶金建设任务，是冶金建设的“国家队”。（中国五矿集团公司）

Suggested translation: As a leading global resources company, we boast the world's largest reserves of tungsten, antimony and bismuth. Responsible for $60 \%$ of the global metallurgical projects, we focus on finding, mining and processing the earth's metal and mineral resources including copper, zinc, nickel, to name some select few. (Click "Our Business" to see our diverse ranges of products)

When Chinese enterprise profiles are translated into English in Example 4, translator tries to reach conciseness and renders the substantive and important information to the target readers by simplifying and rewriting the self-glorifying message in the source text to highlight the enterprise's international competitive strength and to achieve efficient communication in the target language environment.

\section{Conclusions}

With growing awareness of participating in global competition and cooperation, more and more Chinese companies have established their bilingual websites. This thesis, by making a rhetorical comparison of Chinese and American enterprise profiles with respect to arguments, textual arrangements and appeals, summarizes the features and functions of enterprise publicity and argues that the realization of the operative function should be given prior consideration. It also puts forth some translation strategies to ensure that translation of enterprise publicity will be able to reach the intended effects.

It has to be noted that there is still room for improvement about this study. In further study, more examples should be collected and analyzed so that the conclusion will be more objective and applicable.

\section{Acknowledgement}

This research is supported by 2016 Fujian Education and Research Project (Grant NO. JAS160166) and FLTRP College English Research Project (Grant NO. 20150016).

\section{References}

[1] X. Chen: Translation and Rhetoric Revisited (Foreign Language Teaching and Research Press, China 2013), p. 121.

[2] X. Lu, Chinese and American corporate profiles on websites: textual comparison and translation, Chinese Translators Journal, vol. 33 (2012), pp. 92-97.

[3] J. Herrick: The History and Theory of Rhetoric: An Introduction (Pearson, USA 2012), p. 13.

[4] A. Trosborg, Text typology: register, genre and text type, in: Text Typology and Translation, edited by A. Trosborg/Shanghai Foreign Language Education Press, Shanghai (2012), pp. 1-23.

[5] K. Reiss, Text types, translation types and translation assessment, in: Readings in Translation Theory, edited by A. Chesterman/Finn Lectura, Helsinki (1989), pp.105-115.

[6] M. Baker, G. Saldanha: Routledge Encyclopedia of Translation Studies (Routledge, England 2009), p. 116.

[7] C. Nord: Translating as a Purposeful Activity: Functionalist Approaches Explained (St. Jerome Publishing, England 1997), p. 50.

[8] X. Chen: New Coursebook on Pragmatic Translation (Economic Science Press, China 2015), pp. 77-78.

[9] E. Nida, C. Taber: The Theory and Practice of Translation (Koninklijke Brill NV, The Netherlands 2003), p. 208. 